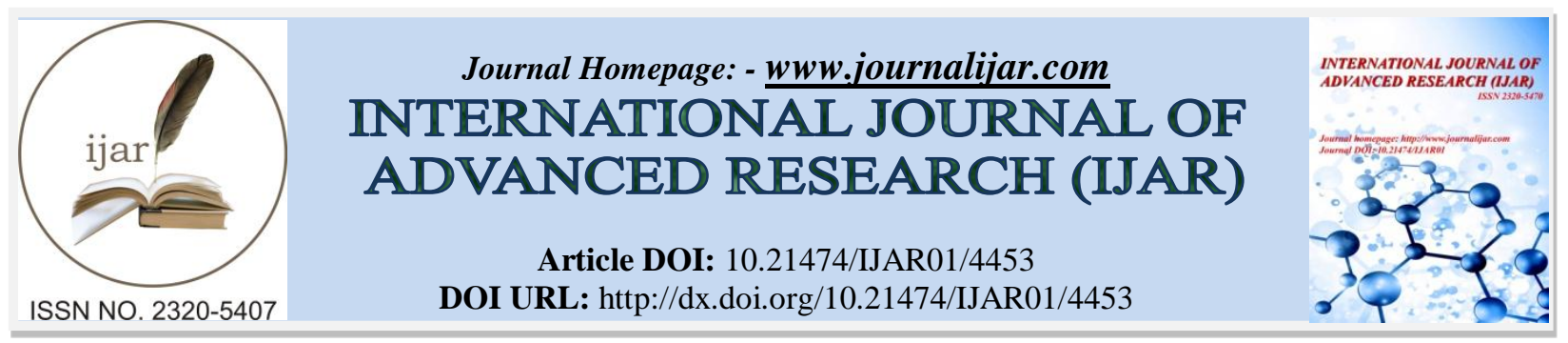

RESEARCH ARTICLE

\title{
THE ANALYSIS OF WONOREJO DAM SLOPE STABILITY BASED ON 2004 AND 2010 EARTHQUAKE MAPS.
}

\author{
Pitojo Tri Juwono ${ }^{1}$, Andre Primantyo $\mathbf{H}^{\mathbf{1}}$ and Nisa Andan Restuti ${ }^{2}$. \\ 1. Lecturer of Study Program of Water Engineering Magister, Brawijaya University, Malang, East Java. \\ 2. Student of Water Engineering Magister, Water Engineering, Brawijaya University, Malang, East Java.
}

\section{Manuscript Info}

..........................

Manuscript History

Received: 12 April 2017

Final Accepted: 14 May 2017

Published: June 2017

Key words:-

stability, NWL, HWL, RDD,

Earthquake Map

\section{Abstract}

The stability of Wonorejo Dam slope is analyzed with modified earthquake parameters based on 2004 and 2010 Earthquake Maps. Security rate in 2004 Earthquake Map is bigger than that in 2010 Earthquake Map in the case of OBE earthquake. For the case of MDE earthquake, the security rate of 2004 Earthquake Map is smaller than 2010 Earthquake Map. Safe limit of repeat period that can be tolerated by Wonorejo Dam is 200 years at earthquake strength of 6.1 Richter Scale (SR).

Copy Right, IJAR, 2017,. All rights reserved.

\section{Introduction:-}

The stability is one condition that must be met in constructing the dam. Otherwise, dam would be subjected to several security problems such as leakage, seepage, landslide, erosion and crack. Dam stability is affected by many factors, such as dam body materials, dam body zoning, slope inclination, base layer, earthquake load, and others.

As written in the Manual of Analysis on Pile-Type Dam Stability Against Earthquake Load, dam security factor is understood using earthquake coefficient and vibration style. Both items work in the always changing direction and mostly, it fixates into one horizontal static style. It must be modified because pile-type dam is more flexible with earthquake accelerates more at peak. Computer program is used in favor of work effectiveness and optimal result with satisfying quality. Until now, Wonorejo Dam is subjected to periodic examination at the interval 3-months, 6months, and annual. Upscale check is not yet conducted.

Relevant theories or findings from previous studies are used for supplementary data. One of them is considered by the author as must be elaborated in separate section, and that is previous studies with relevant issue that still has connection with current discussion. Focus of previous studies is given to the issue of dam stability. Current study also takes this issue as the topic but analyzes it with 2004 Earthquake Map. However, the author finds difficulty in finding journals discussing dam stability that is analyzed using 2010 Earthquake Map. Therefore, due to this limitation, present study will only explain the analysis of dam stability with 2004 Earthquake Map.

But, the count of earthquake coefficient still uses as reference both 2004 Earthquake Map and 2010 Earthquake Map. 


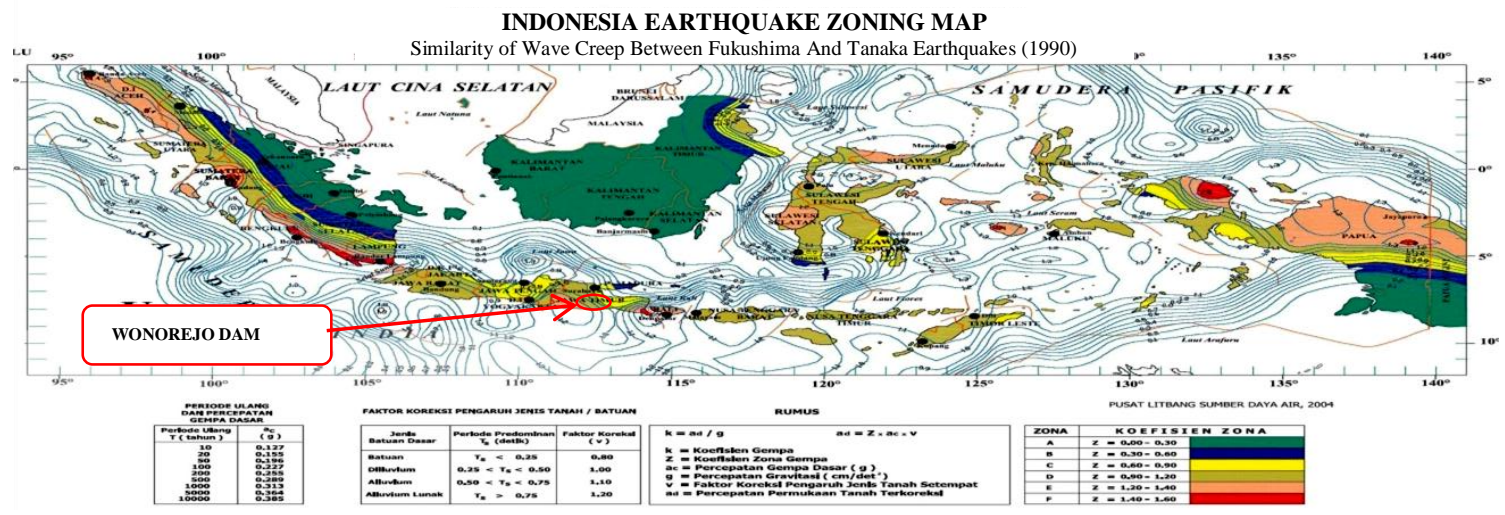

Figure 1:- Wonorejo Dam Location on the 2004 Indonesia Earthquake Zone Map Source: Manual of Analysis on Pile-Type Dam Stability Against Earthquake Load

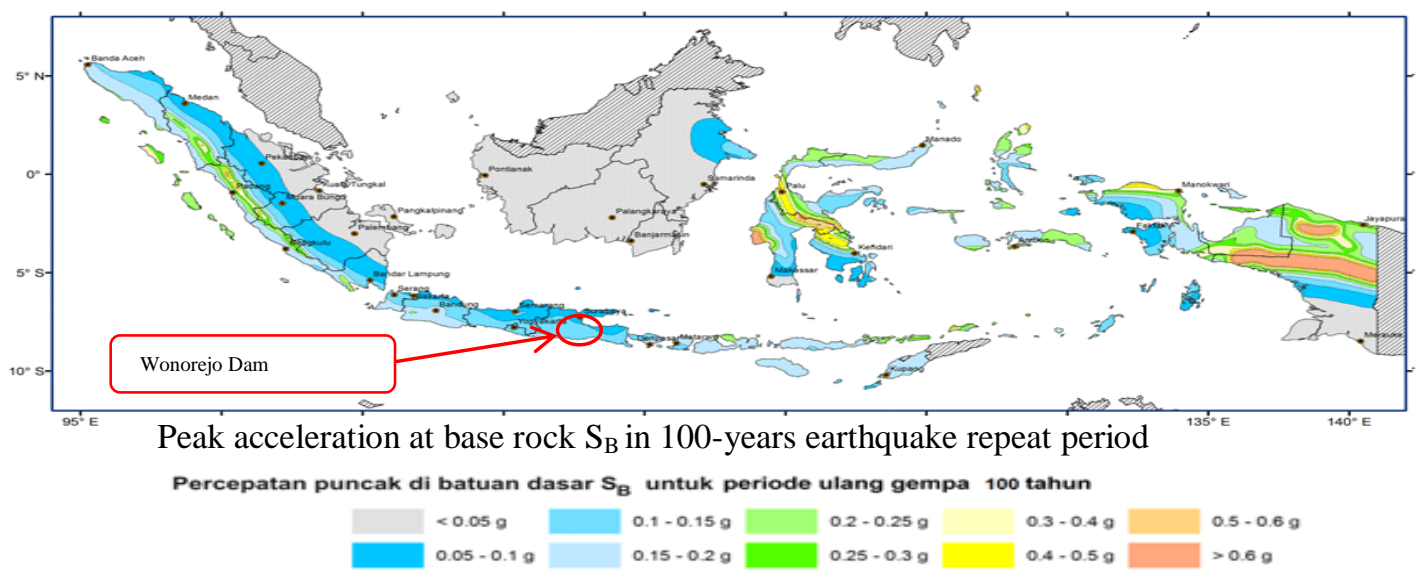

Figure 2:- Wonorejo Dam Location on The 2010 Earthquake Map at 100-Year Earthquake Repeat Period Source: The Manual of Indonesia Earthquake Hazard Map, 2010

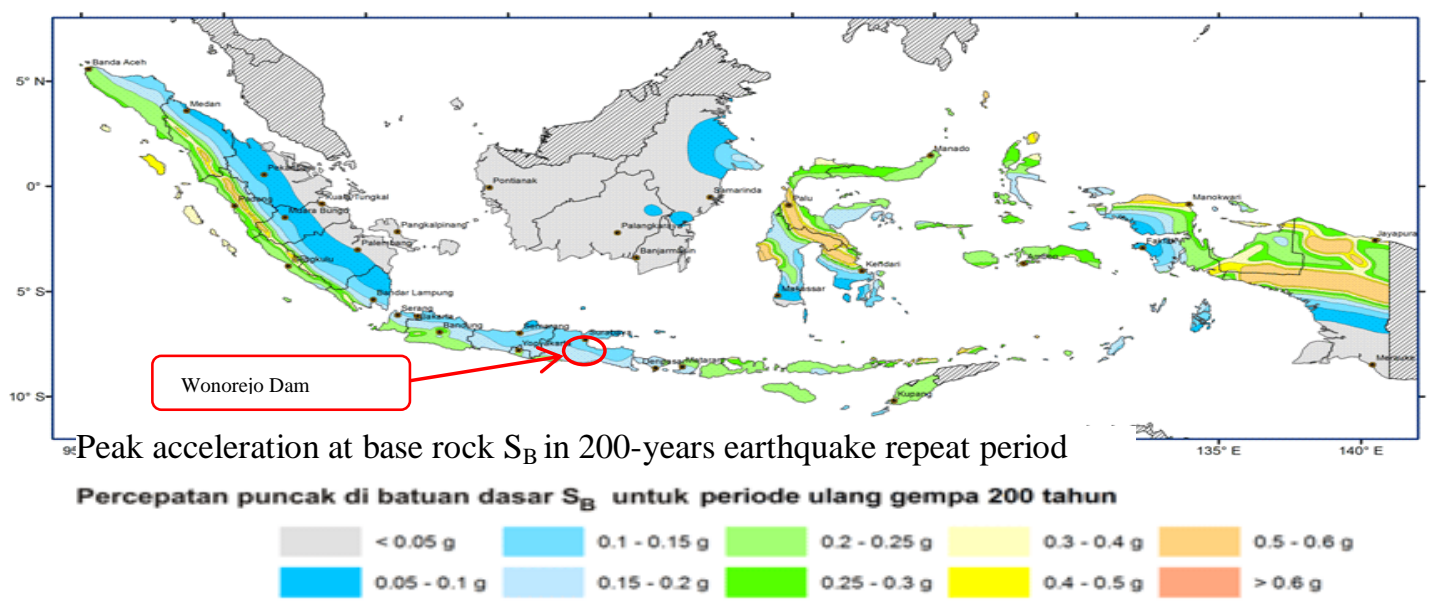

Figure 3:- Wonorejo Dam Location on The 2010 Earthquake Map at 200-Years Earthquake Repeat Period Source: The Manual of Indonesia Earthquake Hazard Map, 2010 


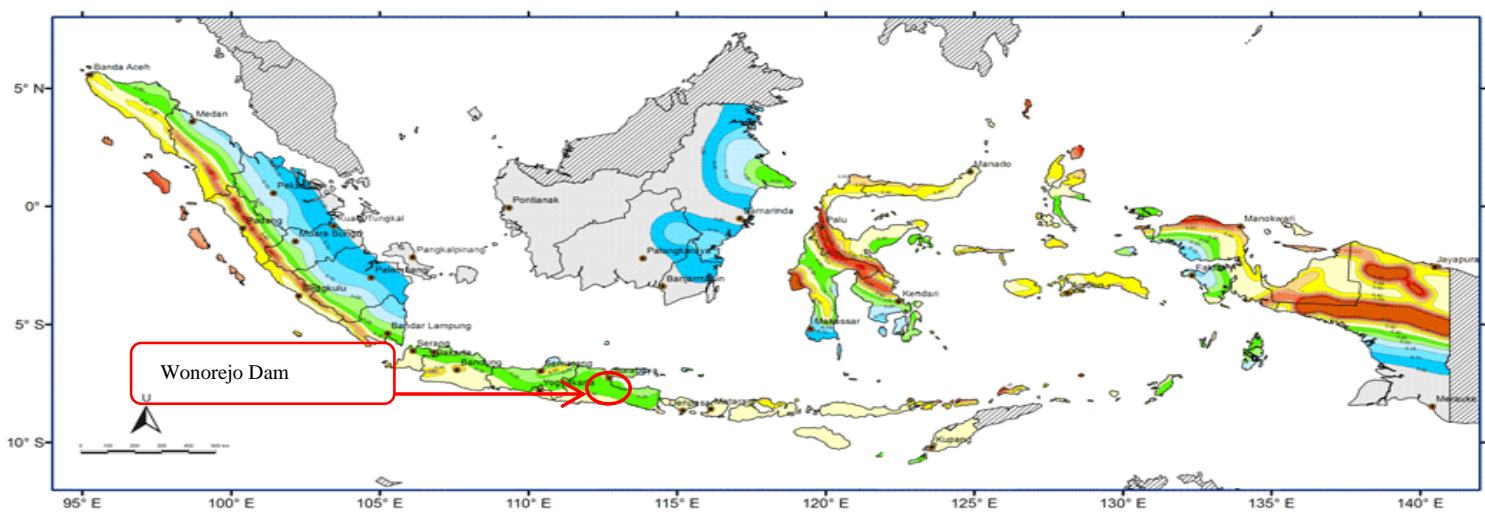

Percepatan puncak di batuan dasar $S_{8}$ untuk probabilitas terlampaui $10 \%$ dalam 100 tahun

\begin{tabular}{|c|c|c|c|c|c|}
\hline$<0.05 g$ & $0.1 .0 .15 \mathrm{~g}$ & $0.2 \cdot 0.25 \mathrm{~g}$ & $0.3=0.4 g$ & $0.5=0.6 \mathrm{~g}$ & $0.7 \cdot 0.8 \mathrm{~g}$ \\
\hline و $0.05=0.1$ & $0.15=0.2 \mathrm{~g}$ & $0.25=0.3 \mathrm{~g}$ & $0.4=0.5 \mathrm{~g}$ & $0.6=0.7 \mathrm{~g}$ & $0.8 \cdot 0.9 \mathrm{~g}$ \\
\hline
\end{tabular}

Figure 4:- Wonorejo Dam Location on The 2010 Earthquake Map at 1000-Years Earthquake Repeat Period Source: The Manual of Indonesia Earthquake Hazard Map, 2010

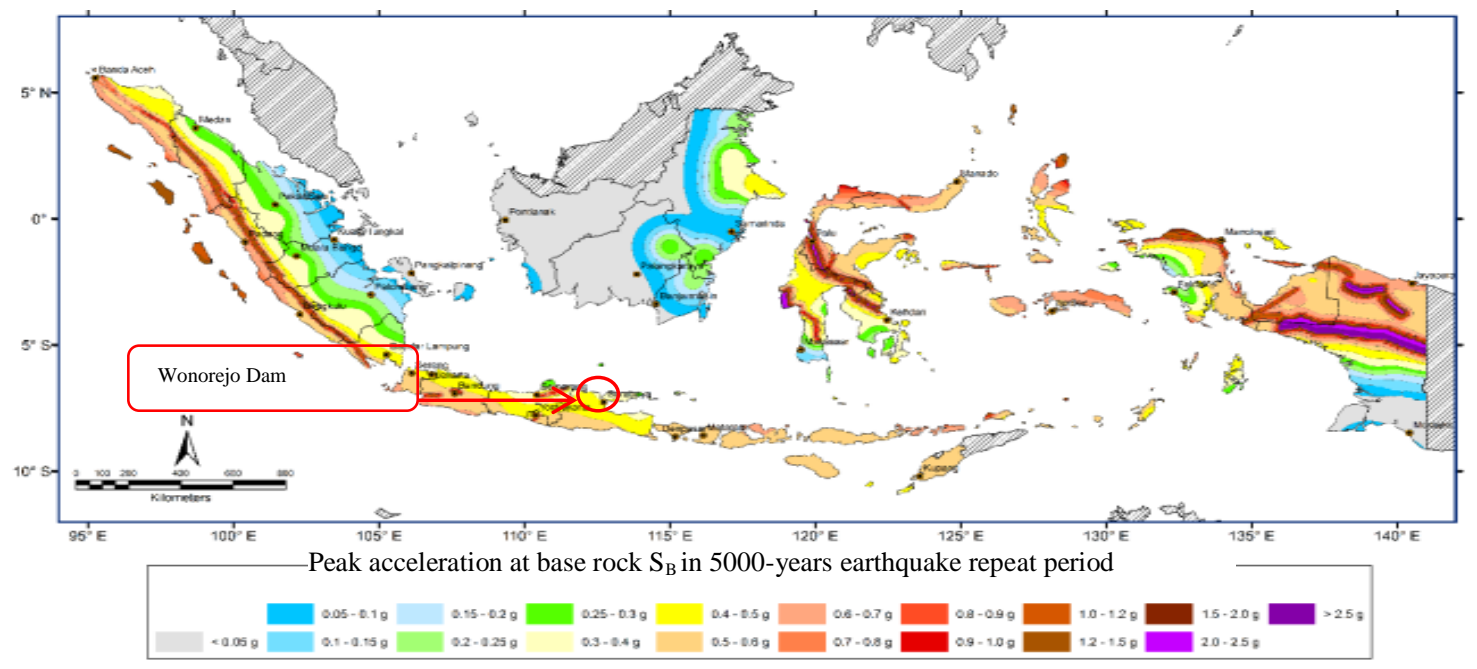

Figure 5:- Wonorejo Dam Location on The 2010 Earthquake Map at 5000-Years Earthquake Repeat Period Source: The Manual of Indonesia Earthquake Hazard Map, 2010 


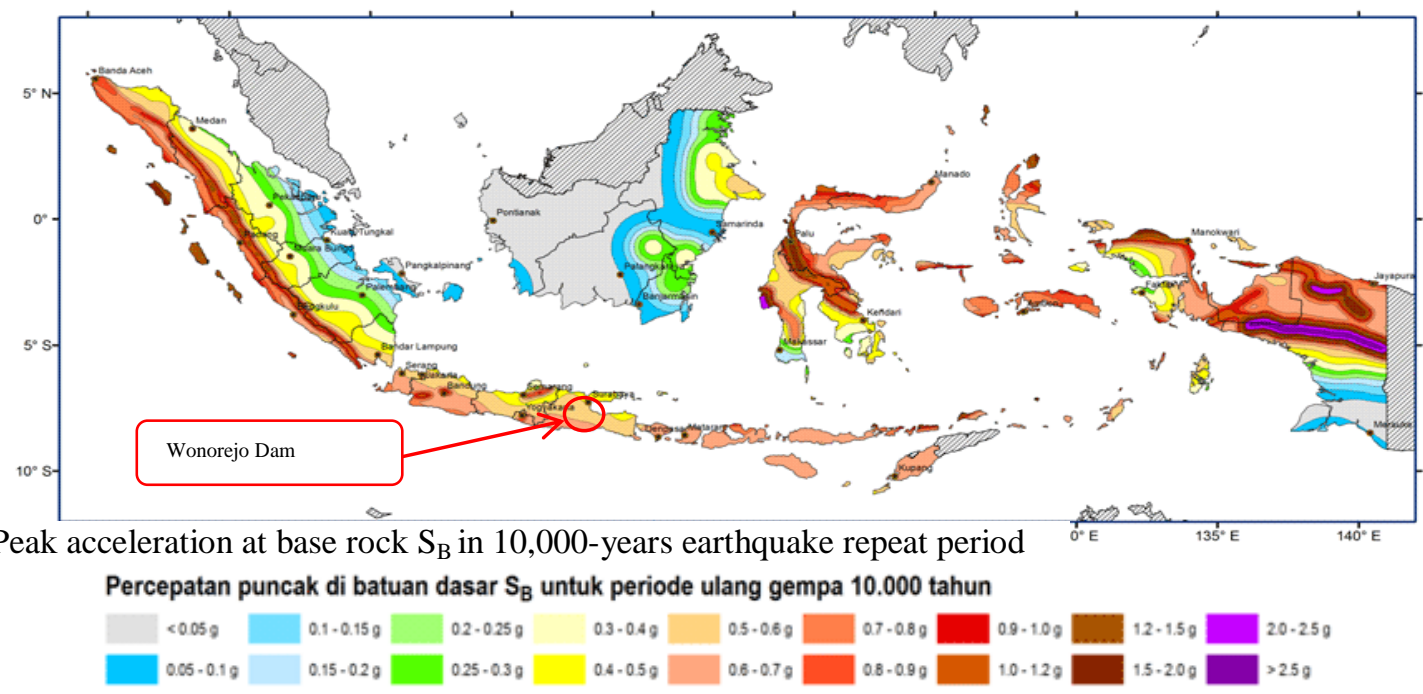

Figure 6:- Wonorejo Dam Location on The 2010 Earthquake Map at 10,000-Year Earthquake Repeat Period Source: The Manual of Indonesia Earthquake Hazard Map, 2010

In general, the stability of Wonorejo Dam slope is already good as shown by the following photographs (PJT I, 2015):

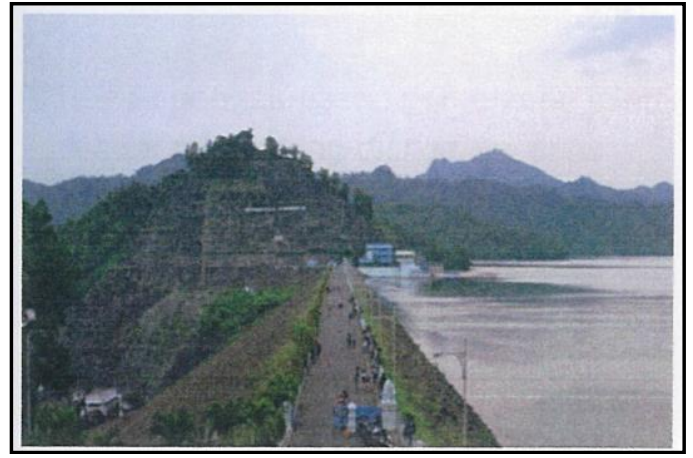

Figure 7:- The Photograph of Wonorejo Dam Peak Condition Source: PJT I, 2015

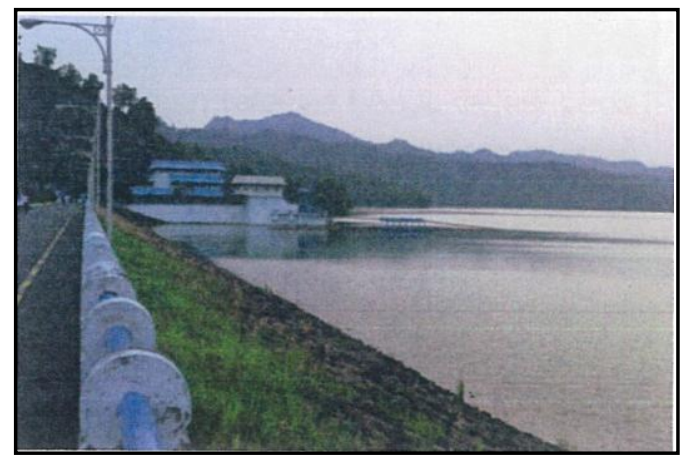

Figure 8. The Photograph of Wonorejo Dam Upstream Slope Condition Source: PJT I, 2015 


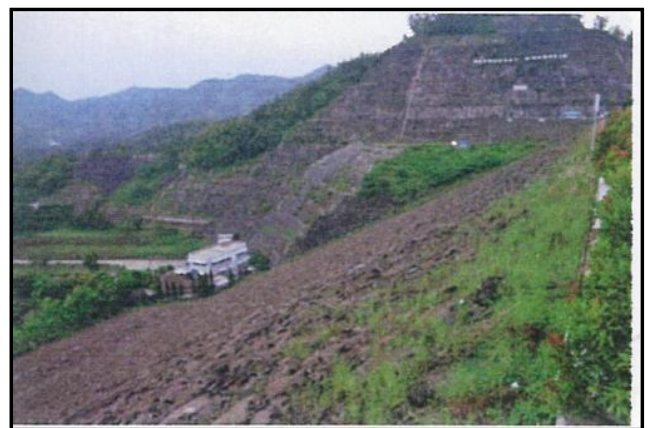

Figure 9:- The Photograph of Wonorejo Dam Downstream Slope Condition Source: PJT I, 2015

Based on these photographs, it is shown that recent visual conditions, including upstream slope, downstream slope, and peak of Wonorejo Dam are in good condition. However, there is no information about improvement done to increase the stability of Wonorejo Dam slope.

\section{Data And Methodology:-}

\section{Data:-}

Data for this study are secondary data relevant with the analysis of Wonorejo Dam slope stability. The required data include:

1. The 2004 and 2010 Earthquake Maps

2. Data of dam geometry

3. Data of pile material parameters

4. Data of reservoir water level elevation

5. Data of piezometer instrumentation

\section{Methodology:-}

The analysis of dam slope stability against earthquake is performed with a programming. Computer program used for this analysis is Geoslope (Flexid=9-38529334). This program can measure dam slope stability by analyzing the static and dynamic condition of the dam. This program allows reader to understand whether the existing dam is safe or not against the effect of seismic load possibly emerging at dam location or around the dam. Method used by study includes Bishop Method and Morgenstern-Price Method.

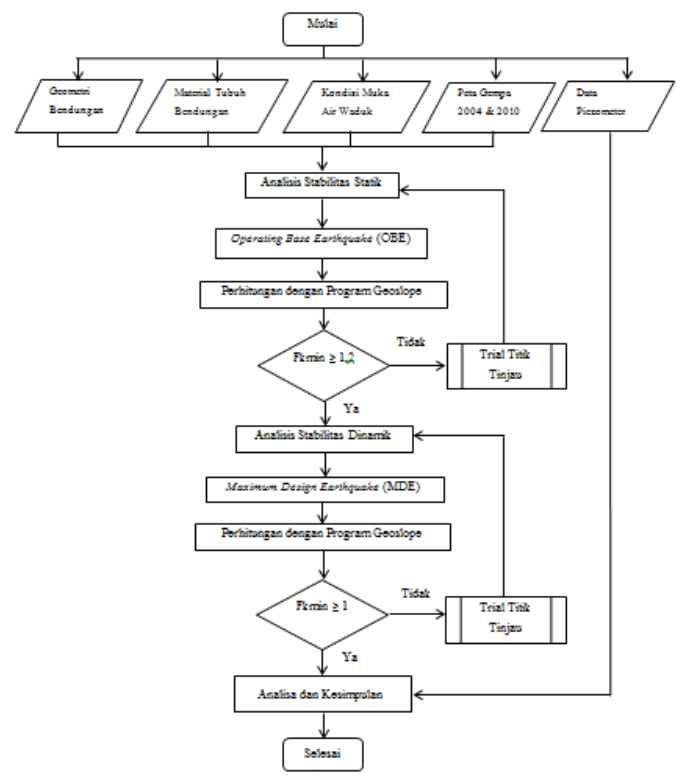

Figure 7:- Flow Diagram of Study. 
The conditions of dam are used as input. These include:

1. Condition after construction without and with earthquake.

2. Low water level (LWL), $\pm 141.00 \mathrm{~m}$, without and with earthquake.

3. Normal water level (NWL), $\pm 183.00 \mathrm{~m}$, without and with earthquake.

4. Flood water level (HWL), $\pm 185.00 \mathrm{~m}$, without and with earthquake.

5. Fast ebb (NWL to LWL), $\pm 183.00 \mathrm{ke} \pm 141.00 \mathrm{~m}$, without and with earthquake.

Some paremeters of Wonorejo Dam body pile are used in the simulation. These data are displayed in the table.

Table 1:- Data of Wonorejo Dam Body Material.

\begin{tabular}{|c|c|c|c|c|c|c|c|}
\hline Zone & \multirow[t]{2}{*}{ Material } & \multirow[t]{2}{*}{ Gs } & \multicolumn{3}{|c|}{ Density $\left(\mathrm{t} / \mathrm{m}^{3}\right)$} & \multicolumn{2}{|c|}{ Shear Strength } \\
\hline No. & & & Dry & Wet (OMC) & Saturated & $\mathrm{C}\left(\mathrm{t} / \mathrm{m}^{2}\right)$ & $\varnothing\left(^{\circ}\right)$ \\
\hline 1 & Impervious & 2.70 & 1.24 & 1.68 & 1.78 & 2.0 & 28 \\
\hline 2 & Filter & 2.60 & 2.07 & 2.22 & 2.27 & - & 36 \\
\hline 3 & Excavated rock material & 2.70 & 1.73 & 1.80 & 2.09 & - & 36 \\
\hline 4 & Sand and gravel & 2.60 & 1.83 & 2.08 & 2.13 & - & 35 \\
\hline 5 & Rock & 2.75 & 1.78 & 1.82 & 2.14 & - & 40 \\
\hline $5 \mathrm{R}$ & Rock riprap & 2.75 & 1.81 & 1.82 & 2.15 & - & 42 \\
\hline
\end{tabular}

Source : Design Criteria for Civil Works Report

\section{Result and Discussion:-}

The result obtained is derived from calculation and simulation of dam body. It is explained as following:

The parameters of earthquake rate and dam design are determined based on the Manual of Analysis on Pile-Type Dam Stability Against Earthquake Load and the 2010 Manual of Indonesia Earthquake Hazard Map. The analysis on Wonorejo Dam slope stability against earthquake starts by determining the security factor of the dam, followed by determining the criteria of earthquake repeat period, and ended by analyzing earthquake coefficient with the estimated earthquake repeat period.

From the 2004 Earthquake Map, earthquake coefficient is obtained and it is shown in Table 2.

Table 2:- Recapitalization of Modified Earthquake Coefficient Rate (the 2004 Earthquake Map)

\begin{tabular}{|c|c|c|c|c|c|c|c|c|c|}
\hline \multirow{2}{*}{ No. } & \multirow{2}{*}{$\begin{array}{c}\text { Repeat Period } \\
\text { T (Year) }\end{array}$} & \multirow{2}{*}{$\begin{array}{l}\mathbf{a}_{\mathbf{d}} \\
(\mathrm{g})\end{array}$} & \multirow{2}{*}{$\begin{array}{l}\mathbf{K}_{0} \\
(\mathbf{g})\end{array}$} & \multirow{2}{*}{$\begin{array}{l}\text { Kh } \\
(\mathbf{g})\end{array}$} & \multicolumn{4}{|c|}{ Kh at $\mathbf{y} / \mathbf{H}$} & \multirow{2}{*}{ Remark } \\
\hline & & & & & 1 & 0.75 & 0.5 & 0.25 & \\
\hline 1 & 100 & 0.218 & 0.218 & 0.109 & 0.153 & 0.169 & 0.185 & 0.222 & $\mathrm{OBE}$ \\
\hline 2 & 200 & 0.245 & 0.245 & 0.122 & 0.171 & 0.190 & 0.208 & 0.249 & \\
\hline 3 & 1000 & 0.300 & 0.300 & 0.150 & 0.210 & 0.233 & 0.255 & 0.306 & \\
\hline 4 & 5000 & 0.349 & 0.349 & 0.175 & 0.245 & 0.271 & 0.297 & 0.356 & MDE \\
\hline 5 & 10000 & 0.370 & 0.370 & 0.185 & 0.259 & 0.286 & 0.314 & 0.377 & \\
\hline
\end{tabular}

Source: Result of Calculation

Table 2:- Recapitalization of Modified Earthquake Coefficient Rate (the 2010 Earthquake Map).3

\begin{tabular}{|c|c|c|c|c|c|c|c|c|}
\hline \multirow[t]{2}{*}{ No. } & \multirow{2}{*}{$\begin{array}{l}\text { Repeat Period } \\
\text { T (Year) }\end{array}$} & \multirow{2}{*}{$\frac{\mathrm{PGA}_{\mathrm{M}}}{\text { (g) }}$} & \multirow{2}{*}{$\begin{array}{l}\mathbf{K}_{\mathbf{0}} \\
(\mathbf{g})\end{array}$} & \multirow{2}{*}{$\frac{\mathrm{Kh}}{(\mathrm{g})}$} & \multicolumn{4}{|c|}{ Kh at $\mathbf{y} / \mathbf{H}$} \\
\hline & & & & & 1 & 0.75 & 0.5 & 0.25 \\
\hline 1 & 100 & 0.150 & 0.150 & 0.075 & 0.105 & 0.116 & 0.128 & 0.153 \\
\hline 2 & 200 & 0.200 & 0.200 & 0.100 & 0.140 & 0.155 & 0.170 & 0.204 \\
\hline 3 & 1000 & 0.300 & 0.300 & 0.150 & 0.210 & 0.233 & 0.255 & 0.306 \\
\hline 4 & 5000 & 0.500 & 0.500 & 0.250 & 0.350 & 0.388 & 0.425 & 0.509 \\
\hline 5 & 10000 & 0.600 & 0.600 & 0.300 & 0.420 & 0.465 & 0.510 & 0.611 \\
\hline
\end{tabular}

Source: Result of Calculation

Table 4:- Result of Earthquake Coefficient Calculation using 2004 and 2010 Earthquake Maps at T=100 years

\begin{tabular}{|l|l|l|l|}
\hline No. & Parameters & 2004 Earthquake Map & 2010 Earthquake Map \\
\hline 1 & Base earthquake acceleration & & \\
\hline & $\mathrm{a}_{\mathrm{c}}$ & 0.227 & \\
\hline & $\mathrm{S}_{\mathrm{B}}$ & & 0.150 \\
\hline 2 & Corrected earthquake acceleration & & \\
\hline
\end{tabular}




\begin{tabular}{|l|l|l|l|}
\hline & $\mathrm{a}_{\mathrm{d}}=\mathrm{z} \mathrm{X} \mathrm{a}_{\mathrm{c}} \mathrm{X} \mathrm{v}$ & 0.218 & \\
\hline & $\mathrm{PGA}_{\mathrm{M}}=\mathrm{F}_{\mathrm{PGA}} \times \mathrm{S}_{\mathrm{B}}$ & & 0.150 \\
\hline 3 & Corrected earthquake coefficient & 0.218 & 0.150 \\
\hline 4 & Horizontal earthquake coefficient & 0.109 & 0.075 \\
\hline
\end{tabular}

\section{Result of Calculation:-}

Simulation is done using Geoslope and involving Bishop Method and Morgenstern-Price Method. Data of dam material are adjusted to data of dam pile zoning material. The inputted data include soil specific weight, soil cohesion, and soil shift angle. In addition, pore water pressure is also important input especially its adjustment to both conditions of simulation and water level elevation in the reservoir.

\section{Result of simulation with Geoslope Program is described as Following:- Analysis on Stability Simulation Result without Earthquake:-}

Result of simulation is described in Table 5.

Table 5:- Result of Analysis on Wonorejo Dam Slope Stability after Construction Without Earthquake.

\begin{tabular}{|c|c|c|c|}
\hline \multicolumn{2}{|c|}{ Condition } & Required Security Factor & Obtained Security Factor \\
\hline \multirow{2}{*}{ After Construction } & Upstream & 1.3 & 1.639 \\
\cline { 2 - 4 } & Downstream & 1.3 & 1.804 \\
\hline
\end{tabular}

Source: Result of Calculation

From Table 5, it is known that Wonorejo Dam slope stability after construction without earthquake load at upstream and downstream sections has met the required security factor, respectively higher than 1.3.

Table 6:- Result of Analysis on Wonorejo Dam Slope Stability without Earthquake

\begin{tabular}{|c|c|c|c|c|}
\hline No. & \multicolumn{2}{|c|}{ Conditions } & Required Security Factor & Obtained Security Factor \\
\hline \multirow[t]{2}{*}{1} & \multirow[t]{2}{*}{ LWL } & Upstream & & 1.593 \\
\hline & & Downstream & & 1.803 \\
\hline \multirow[t]{2}{*}{2} & \multirow[t]{2}{*}{ NWL } & Upstream & 1.5 & 1.619 \\
\hline & & Downstream & 1.5 & 1.804 \\
\hline \multirow[t]{2}{*}{3} & \multirow[t]{2}{*}{ HWL } & Upstream & 1.3 & 1.490 \\
\hline & & Downstream & 1.3 & 1.804 \\
\hline \multirow[t]{2}{*}{4} & \multirow{2}{*}{$\begin{array}{c}\text { RDD (NWL - } \\
\text { LWL) }\end{array}$} & Upstream & 1.3 & 1.430 \\
\hline & & Downstream & 1.3 & 1.803 \\
\hline
\end{tabular}

Source: Result of Calculation

Table 6 indicates that Wonorejo Dam slope stability without earthquake load at some conditions of reservoir elevation, such as at NWL, HWL and RDD, has met the required security factor.

\section{Analysis on Stability Simulation Result using the 2004 Earthquake Map}

Table 7:- Result of Analysis on Wonorejo Dam Slope Stability after Construction With Earthquake (the 2004 Earthquake Map)

\begin{tabular}{|c|c|c|c|c|c|c|c|}
\hline \multirow[t]{2}{*}{ No. } & \multirow{2}{*}{\multicolumn{2}{|c|}{ Repeat Period }} & \multirow{2}{*}{$\begin{array}{l}\text { Required } \\
\text { Factor }\end{array}$} & \multicolumn{4}{|c|}{ Obtained Security Factor } \\
\hline & & & & $\mathrm{y} / \mathrm{h}=0.25$ & $y / h=0.50$ & $\mathrm{y} / \mathrm{h}=0.75$ & $y / h=1$ \\
\hline \multirow[t]{2}{*}{1} & \multirow[t]{2}{*}{100} & Upstream & 1.2 & 1.057 & 1.276 & 1.134 & 1.232 \\
\hline & & Downstream & 1.2 & 1.226 & 1.334 & 1.237 & 1.227 \\
\hline \multirow[t]{2}{*}{2} & \multirow[t]{2}{*}{200} & Upstream & 1.2 & 0.926 & 1.202 & 1.028 & 1.228 \\
\hline & & Downstream & 1.2 & 1.058 & 1.265 & 1.185 & 1.232 \\
\hline \multirow[t]{2}{*}{3} & \multirow[t]{2}{*}{1.000} & Upstream & 1.2 & 0.918 & 1.064 & 1.129 & 1.069 \\
\hline & & Downstream & 1.2 & 1.030 & 1.142 & 1.197 & 1.260 \\
\hline \multirow[t]{2}{*}{4} & \multirow[t]{2}{*}{5.000} & Upstream & 1.0 & 0.907 & 0.952 & 0.961 & 0.923 \\
\hline & & Downstream & 1.0 & 0.871 & 0.966 & 1.014 & 1.065 \\
\hline \multirow[t]{2}{*}{5} & \multirow[t]{2}{*}{10.000} & Upstream & 1.0 & 0.753 & 0.713 & 0.727 & 0.825 \\
\hline & & Downstream & 1.0 & 0.901 & 0.939 & 0.987 & 1.037 \\
\hline
\end{tabular}

Source: Result of Calculation 
Analysis on Stability Simulation Result using the 2010 Earthquake Map:-

Table 8:- Result of Analysis on Wonorejo Dam Slope Stability after Construction With Earthquake (the 2010 Earthquake Map)

\begin{tabular}{|c|c|c|c|c|c|c|c|}
\hline \multirow[t]{2}{*}{ No. } & \multirow{2}{*}{\multicolumn{2}{|c|}{ Repeat Period }} & \multirow{3}{*}{$\begin{array}{l}\text { Required } \\
\text { Factor } \\
1.2\end{array}$} & \multicolumn{4}{|c|}{ Obtained Security Factor } \\
\hline & & & & $\mathrm{y} / \mathrm{h}=0.25$ & $\mathrm{y} / \mathrm{h}=0.50$ & $\mathrm{y} / \mathrm{h}=0.75$ & $\mathrm{y} / \mathrm{h}=1$ \\
\hline \multirow[t]{2}{*}{1} & \multirow[t]{2}{*}{100} & Upstream & & 1.057 & 1.276 & 1.134 & 1.232 \\
\hline & & Downstream & 1.2 & 1.227 & 1.346 & 1.381 & 1.415 \\
\hline \multirow[t]{2}{*}{2} & \multirow[t]{2}{*}{200} & Upstream & 1.2 & 0.826 & 1.202 & 1.028 & 1.228 \\
\hline & & Downstream & 1.2 & 1.153 & 1.265 & 1.185 & 1.232 \\
\hline \multirow[t]{2}{*}{3} & \multirow[t]{2}{*}{1.000} & Upstream & 1.2 & 0.918 & 1.064 & 1.129 & 1.069 \\
\hline & & Downstream & 1.2 & 1.030 & 1.142 & 1.197 & 1.260 \\
\hline \multirow[t]{2}{*}{4} & \multirow[t]{2}{*}{5.000} & Upstream & 1.0 & 0.907 & 0.952 & 0.961 & 0.923 \\
\hline & & Downstream & 1.0 & 0.871 & 0.966 & 1.014 & 1.065 \\
\hline \multirow[t]{2}{*}{5} & \multirow[t]{2}{*}{10.000} & Upstream & 1.0 & 0.753 & 0.713 & 0.727 & 0.825 \\
\hline & & Downstream & 1.0 & 0.901 & 0.939 & 0.987 & 1.037 \\
\hline
\end{tabular}

Source: Result of Calculation

As shown by Table 7, Wonorejo Dam slope stability after construction with earthquake load, based on the 2004 Earthquake Map, indicates a fact that some load combinations do not meet security requirements.

Table 8 indicates that Wonorejo Dam slope stability after construction with earthquake load, based on the 2010 Earthquake Map, has shown a fact that some load combinations do not meet security requirements.

Wonorejo Dam slope stability is analyzed based on both 2004 and 2010 Earthquake Maps. The process is described as following:

1. The analysis on upstream slope stability with 100-years and 200-years repeat period based on the 2004 Earthquake Map is done already. Security factor rate tends to be smaller than that based on the 2010 Earthquake Map. Meanwhile, downstream slope stability based on the 2004 Earthquake Map has produced smaller security factor rate than that based on the 2010 Earthquake Map. However, the difference between these two earthquake maps is not quite significant.

2. The analysis on upstream slope stability at 1000-years repeat period is performed. Security factor rate of Wonorejo Dam slope stability at upstream section based on the 2004 Earthquake Map is almost similar with that based on the 2010 Earthquake Map. The analysis of downstream slope stability has produced security factor rate that is almost similar between the 2004 Earthquake Map and the 2010 Earthquake Map, because the difference is not quite significant.

3. The stability on upstream and downstream slopes with repeat period of 5,000 years and 10,000 years has been subjected to analysis. Security factor rate at upstream slope of Wonorejo Dam, based on the 2004 Earthquake Map, has produced bigger security factor rate than that based on the 2010 Earthquake Map.

\section{Safety Limit of Earthquake Repeat Period in Wonorejo Dam:-}

Pursuant to historical earthquake data from U.S. Geological Survey (USGS), some earthquake events are then used to determine safe limit of earthquake repeat period at Richter Scale.

Safe limit of repeat period that can be tolerated by Wonorejo Dam is 200 years at earthquake strength of 6.1 Richter Scale (SR).

Recommendation:-

Given the result of analysis on Wonorejo Dam, it is suggested that damp should be operated in normal condition. It is not recommended to operate dam at emergency case because it may affect dam slope stability.

\section{Conclusion:-}

Concerning with the analysis of Wonorejo Dam slope stability with modified earthquake parameters based on the 2004 Earthquake Map and the 2010 Earthquake Map, some conclusions are made:

1) The condition of Wonorejo Dam slope stability after analyzing it based on 2004 and 2010 earthquake maps is described as following: 
a) Result of analysis on upstream slope stability with 100-years and 200-years repeat period has produced a fact that the resultant security factor rate based on the 2004 Earthquake Map tends to be smaller than that based on the 2010 Earthquake Map. The analysis on downstream slope stability has resulted in smaller security factor rate than that based on the 2010 Earthquake Map, but difference between these results is not quite significant.

b) Result of analysis on upstream slope stability at 1,000-years repeat period has revealed a fact that security factor rate of Wonorejo Dam slope stability at upstream section based on the 2004 Earthquake Map is almost similar to that based on the 2010 Earthquake Map. The analysis on downstream slope stability as measured based on the 2004 Earthquake Map and the 2010 Earthquake Map has produced security factor rate that is almost similar among both because the difference is not quite significant.

c) Result of analysis on the stability of upstream and downstream slopes with repeat period of 5,000 years and 10,000 years has discovered a fact that security factor rate at upstream slope of Wonorejo Dam, based on the 2004 Earthquake Map, has bigger security factor rate than that based on the 2010 Earthquake Map.

2) Earthquake coefficient measured with each earthquake map is explained as following:

a) Earthquake coefficient rate at 100-years and 200-years repeat period based on the 2004 Earthquake Map is greater than that based on the 2010 Earthquake Map. Security factor rate based on the 2004 Earthquake Map is smaller than security factor rate in the 2010 Earthquake Map.

b) The 1,000-years repeat period has produced similar rates of earthquake coefficient on both earthquake maps, and thus, both security factor rates are almost similar.

c) At 5,000-years and 10,000-years repeat period, earthquake coefficient rate based on the 2004 Earthquake Map is almost a half smaller than that based on the 2010 Earthquake Map. Thus, the 2004 Earthquake Map produces security factor rate that is bigger than that in the 2010 Earthquake Map.

The resultant conditions of Wonorejo Dam slope stability from measurement with both 2004 and 2010 Earthquake Maps are set into comparison. The result shows that almost all security factor rates do not meet the requirement. If the stability is counted at the condition after construction without earthquake, all conditions of water level elevation are meeting the minimum security factor rate.

3) Safe limit of repeat period that can be tolerated by Wonorejo Dam is 200 years. The reason is bcause in this repeat period, Wonorejo Dam slope stability remains below the limit of security factor rate. Safe limit of this repeat period is equivalent to $6.1 \mathrm{SR}$.

The result of analysis on Wonorejo Dam provides recommendation. It is recommended that damp should be operated in normal condition. It is not recommended to operate dam at emergency case because it may affect dam slope stability.

\section{References:-}

1. Departemen Permukiman Dan Prasarana Wilayah. 2004. Analisis Stabilitas Ben-dungan Tipe Urugan Akibat Beban Gempa. Jakarta: Balai Ben-dungan.

2. Dharmawangsa, IGN Putu. 2014. Analisis Keamanan Lereng Bendungan Uta-ma Pada Bendungan Benel Di Kabupaten Jembrana. Jurnal Spek-tran. Vol 2 No 2, Juli 2014.

3. Dewa, Ghea Wedya Rangga. 2014. Analisa Stabilitas Tubuh Bendungan Lolak Kabupaten Bolaang Mongondow Sulawesi Utara. Skripsi. Tidak Dipublikasi. Malang: Universitas Brawijaya.

4. Hanan, Zaid Ramadhan. 2014. Analisis Stabilitas Lereng Bendungan Jati-gede dengan Parameter Gempa Termodifikasi. Skripsi. Tidak Dipu-blikasi. Malang: Universitas Bra-wijaya.

5. Hasani, H. 2013. Stability of Slope and Seepage Analysis in Earth Fills Dams Using Numerical Models (Case Study: Ilam DAM-Iran). World Applied Sciences Journal 21 (9): 1398-1402.

6. Kementerian Pekerjaan Umum. 2011. Metode Analisis Stabilitas Lereng Statik Bendungan Urugan. Jakarta: Balai Bendungan.

7. Nippon Koei. 1992. Design Criteria for Civil Works. Jakarta: Tidak diterbitkan.

8. Perusahaan Umum Jasa Tirta I. 2015. Laporan Triwulan I Analisa dan Evaluasi Keamanan Tubuh Bendungan. Malang: Tidak Diterbitkan.

9. Republik Indonesia. 2010. Peta Hazard Gempa Indonesia 2010 Sebagai Acuan Dasar Perencanaaan Dan Perancangan Infrastruktur Tahan Gempa. Jakarta: Kementerian Pekerjaan Umum.

10. http://earthquake.usgs.gov/earthquakes/search. Diakses tanggal 4 Agustus 2015. 